Original Article

\title{
CYTOTOXIC AND ANTIOXIDANT ACTIVITIES OF SECONDARY METABOLITES FROM PULICARIA UNDULATA
}

\author{
TAHA A. HUSSIEN ${ }^{*}$, SAYED A. EL-TOUMY ${ }^{2}$, HOSSAM M. HASSAN ${ }^{1}$, MONA H. HETTA ${ }^{3}$
}

${ }^{1}$ Department of Pharmacognosy, Faculty of Pharmacy, Beni-Suef University, Egypt, ${ }^{2}$ Chemistry of Tannins Department, National Research Center, El-Bohouth St., Dokki, 12622 Cairo, Egypt, ${ }^{3}$ Department of Pharmacognosy, Faculty of Pharmacy, Fayoum University 63514, Egypt Email: thussien71@yahoo.com

Received: 13 May 2016 Revised and Accepted: 22 Jul 2016

\section{ABSTRACT}

Objective: To evaluate the in vitro cytotoxicity, antioxidant activities and structure-activity relationship of secondary metabolites isolated from Pulicaria undulata.

Methods: The methylene chloride-methanol (1:1) extract of the air-dried aerial parts of Pulicaria undulata was fractionated and separated to obtain the isolated compounds by different chromatographic techniques. Structures of the isolated compounds were determined on the basis of the extensive spectroscopic analysis, including 1D and 2D NMR and compared with the literature data. The crude extract and the isolated compounds were evaluated for in vitro antioxidant activity using the 2,2 diphenyl dipicryl hydrazine (DPPH) method and cytotoxic assay using human breast cancer (MCF-7) and hepatoma (Hep G2) cell line.

Results: Nine secondary metabolites were isolated from Pulicaria undulata in this study. Of which two terpenoidal compounds; 8-epi-ivalbin and $11 \beta$, 13-dihydro-4H-xanthalongin 4-O- $\beta$-D-glucopyranoside firstly isolated from the genus pulicaria and three flavonoids; eupatolitin, 6methoxykaempferol, and patulitrin firstly isolated from P. undulata. 6-methoxykaempferol ( $\mathrm{IC}_{50} 2.3 \mu \mathrm{g} / \mathrm{ml}$ ) showed the most potent antioxidant activity. The highest cytotoxic effect against MCF-7 and Hep G2 cells was obtained with eupatolitin (IC 5027.6 and $23.5 \mu \mathrm{g} / \mathrm{ml}$ ) respectively. The structure-activity relationship was also examined and the findings presented here showed that 3, 5, 7, 4' and 3, 5, 4', 5'-hydroxy flavonoids were potent antioxidant and has cytotoxic activity.

Conclusion: Pulicaria undulata is a promising medicinal plant, and our study tends to support the therapeutic value of this plant as antioxidant drug and in the treatment of cancer.

Keywords: Pulicaria undulata, Sesquiterpenes, Ditepenoids, Flavonoids, Cytotoxicity, Antioxidant

(C) 2016 The Authors. Published by Innovare Academic Sciences Pvt Ltd. This is an open access article under the CC BY license (http://creativecommons. org/licenses/by/4. 0/) DOI: http://dx.doi.org/10.22159/ijpps.2016v8i9.12814

\section{INTRODUCTION}

Medicinal plants are a rich source of secondary metabolites with interesting biological activities. Therefore, these secondary metabolites have an important source with a variety of structural arrangements and properties [1-3]. The genus Pulicaria, belonging to the tribe Inuleae of the Asteraceae family, consists of ca. 100 species with a distribution from Europe to North Africa and Asia, particularly around the Mediterranean [4]. Phytochemical analysis of certain Pulicaria species led to the isolation of monoterpene, sesquiterpenes, diterpenes, triterpenes, phenolics, flavonoids and steroids [5]. Various biological activities have been reported for some species of Pulicaria, such as cytotoxic activity of Pulicaria crispa and Pulicaria orientalis [67], antibacterial activity of Pulicaria undulata and Pulicaria dysenterica [8, 9], antimicrobial activity of Pulicaria odor L. [10], antispasmodic activity of Pulicaria glutinosa [11] and antihistaminic effect of Pulicaria dysenterica [12]. Pulicaria undulata (L.) KOSTEL [syn. P. crispa FORSSK. BENTH. et HOOK. f.; Francoeuria crispa (FORSSK.) CASS.] is an annual herb or sometimes a perennial subshrub, producing small bright yellow flower. It is commonly used traditionally to treat inflammation, insect repellent, and even as an herbal tea [13]. As a part of our continuing search for natural antioxidant and cytotoxic agents, an attempt has been made to isolate and elucidate the structures of secondary metabolites from the Pulicaria undulata aerial part.

The antioxidant activities of crude extract $\left(\mathrm{CH}_{2} \mathrm{Cl}_{2} / \mathrm{MeOH}\right)(1: 1)$ and the isolated compounds were evaluated by measuring their ability to scavenge the radical DPPH. Furthermore, the effects of $P$. undulata crude extract and the isolated metabolites on inhibition of cell proliferation in human breast cancer cells (MCF-7) and hepatoma cells (Hep G2) were also examined. In addition, the other objective of this study is to investigate the structure-activity relationship of identified terpenoids and flavonoids.

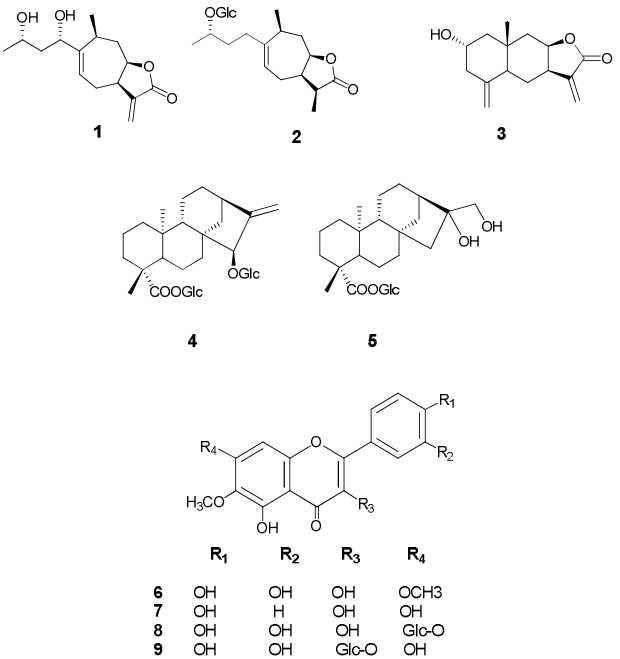

Fig. 1: Structures of the isolated compounds from $P$. undulata in the present study

\section{MATERIALS AND METHODS}

\section{General experimental procedure}

${ }^{\mathrm{I}} \mathrm{H}$ NMR (600 MHz, $\mathrm{CDCl}_{3}$ and $\mathrm{CD}_{3} \mathrm{OD}$ ), ${ }^{13} \mathrm{C}$ NMR (150 MHz, $\mathrm{CDCl}_{3}$ and $\left.\mathrm{CD}_{3} \mathrm{OD}\right)$ and the $2 \mathrm{D}$ spectra $\left({ }^{1} \mathrm{H}-{ }^{-1} \mathrm{H} \mathrm{COSY}, \mathrm{HMQC}\right.$, and $\left.\mathrm{HMBC}\right)$ were recorded on the JEOLEAC $600 \mathrm{MHz}$ spectrometer, with tetramethylsilane (TMS) as an internal standard. The IR spectrum 
(KBr) was taken on a HORIBA FT-720 spectrometer. Optical rotation was determined with the help of an HORIBA SEPA-300 spectropolarimeter. Electron impact mass spectrometry (El-MS) analyses were recorded on a JEOLSX102A mass spectrometer. Column chromatography was carried out on silica gel 60 (Merck; 230-400 mesh) and sephadex LH-20 (Pharmacia Co. Tokyo, Japan). TLC was performed on silica gel $60 \mathrm{~F}_{254}$ plated ( $0.25 \mathrm{~mm}$, Merck Co.), Column chromatography (CC) was carried out on kieslgel 60 (Merck; 230$400 \mathrm{mesh}$ ) and spots were detected under UV light and colored by spraying with $10 \% \mathrm{H}_{2} \mathrm{SO}_{4}$ solution followed by heating.

\section{Plant material}

P. undulata plant was collected in March 2013, from North Sinai, Egypt. A voucher specimen (no. PU-51-03-13) was deposited in the Herbarium of Saint Katherine protectorate, Egypt. The collection was taking place under the permission of Saint Katherine protectorate for scientific purposes.

\section{Extraction and Isolation}

Aerial parts $(1.5 \mathrm{~kg})$ of $P$. undulata were powdered and extracted with $\mathrm{CH}_{2} \mathrm{Cl}_{2} \mathrm{MeOH} \quad(1: 1)$ at room temperature. The extract was concentrated in vacuo to obtain a residue of $112 \mathrm{~g}$. The residue was fractionated by silica gel CC $(6 \times 120 \mathrm{~cm})$ eluted with $n$-hexane $(2500$ $\mathrm{ml}$ ) followed by a gradient of n-hexane- $\mathrm{CHCl}_{3}$ up to $100 \% \mathrm{CH}_{2} \mathrm{Cl}_{2}$ and $\mathrm{CH}_{2} \mathrm{Cl}_{2} \mathrm{MeOH}$ up to $15 \% \mathrm{MeOH}(2000 \mathrm{ml}$ of each solvent mixture) with increasing degree of polarity. The n-hexanechloroform (1:2) fraction (250 mg) was pre-fractionated by CC using sephadex LH-20 $(2 \times 40 \mathrm{~cm})$ and eluted with n-hexane-methylene chloride-methanol 7: 4: $0.5(3000 \mathrm{ml})$. Fractions were obtained and combined into two main portions: A (90 mg) and B (100 mg). Subfraction A was repurified by reversed phase $\mathrm{HPLC}$ using $\mathrm{MeOH} / \mathrm{H}_{2} \mathrm{O}$ (65-30\% $2500 \mathrm{ml}$ ) to afford compound 1 (10 mg), 2 (12 mg), 3 (15 $\mathrm{mg}), 4(10 \mathrm{mg})$ and $5(15 \mathrm{mg})$. Sub-fraction $B$ repurified by reversed phase HPLC using $\mathrm{MeOH} / \mathrm{H}_{2} \mathrm{O}(65-40 \% 1500 \mathrm{ml})$ to afford compound 6 (30 mg), 7 (16 mg), 8 (20 mg) and 9 (22 mg).

\section{8-epi-Ivalbin (1)}

Colourless crystals; IR ( $\left.\mathrm{KBr}, \mathrm{v}_{\max }, \mathrm{cm}^{-1}\right): 1760,1660,1630 ;{ }^{1} \mathrm{H}$ NMR $\left(600 \mathrm{MHz} \mathrm{CDCl}_{3}\right) \delta: 4.23(1 \mathrm{H}, \mathrm{dd}, J=5.5,8.5 \mathrm{~Hz}, \mathrm{H}-2), 1.69(\mathrm{IH}, \mathrm{m}, \mathrm{H}-$

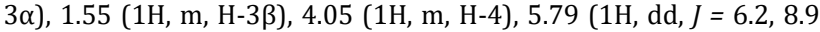
Hz, H-5), 2.43 (1H, m, H-6 $\alpha$ ), 2.30 (1H, m, H-6 $\beta$ ), 3.31 (1H, m, H-7), $4.62(1 \mathrm{H}$, ddd, $J=2.7,9.6,12.3 \mathrm{~Hz}, \mathrm{H}-8), 2.05(1 \mathrm{H}, \mathrm{m}, \mathrm{H}-9 \alpha), 1.81$ $(1 \mathrm{H}, \mathrm{m}, \mathrm{H}-9 \mathrm{\beta}), 2.60(1 \mathrm{H}, \mathrm{m}, \mathrm{H}-10), 6.26(1 \mathrm{H}, \mathrm{d}, J=2.7 \mathrm{~Hz}, \mathrm{H}-13 \alpha)$, $5.52(1 \mathrm{H}, \mathrm{d}, J=2.7 \mathrm{~Hz}, \mathrm{H}-13 \beta), 1.17(3 \mathrm{H}, \mathrm{d}, J=6.2 \mathrm{~Hz}, \mathrm{H}-14), 1.22(3 \mathrm{H}$, d, $J=6.2 \mathrm{~Hz}, \mathrm{H}-15) ;{ }^{13} \mathrm{C}$ NMR $\left(150 \mathrm{MHz}, \mathrm{CDCl}_{3}\right) \delta: 148.5(\mathrm{C}-1), 77.3$ (C-2), 44.4 (C-3), 69.2 (C-4), 122.2 (C-5), 26.1 (C-6), 41.6 (C-7), 79.1 (C-8), 37.0 (C-9), 33.3 (C-10), 138.8 (C-11), 170.1 (C-12), 121.9 (C13), 24.5 (C-14), 22.0 (C-15).

\section{$11 \beta, 13$-dihydro-4H-xanthalongin 4-0- $\beta$-D-glucopyranoside (2)}

Amorphous white powder; ${ }^{1} \mathrm{H}$ NMR (600 MHz, $\left.\mathrm{CD}_{3} \mathrm{OD}\right) \delta: 1.49(1 \mathrm{H}$, $\mathrm{m}, \mathrm{H}-1 \alpha), 1.44(\mathrm{IH}, \mathrm{m}, \mathrm{H}-2 \beta), 1.72(1 \mathrm{H}, \mathrm{m}, \mathrm{H}-3 \alpha), 1.67$ (1H, m, H-3 $\beta$ ), $3.78(1 \mathrm{H}, \mathrm{m}, \mathrm{H}-4), 5.55(1 \mathrm{H}, \mathrm{br} \mathrm{d}, J=10.5 \mathrm{~Hz}, \mathrm{H}-5), 2.13(1 \mathrm{H}, \mathrm{dd}, J=$ 12.0, $12.3 \mathrm{~Hz}, \mathrm{H}-6 \alpha), 2.03(1 \mathrm{H}, \mathrm{m}, \mathrm{H}-6 \beta), 2.10(1 \mathrm{H}, \mathrm{m}, \mathrm{H}-7), 4.58(1 \mathrm{H}$, ddd, $J=2.7,9.6,12.3 \mathrm{~Hz}, \mathrm{H}-8), 2.20(1 \mathrm{H}, \mathrm{dd}, J=2.1,15.0 \mathrm{~Hz}, \mathrm{H}-9 \alpha)$, 1.60 (1H, ddd, $J=2.7,4.1,12.3 \mathrm{~Hz}, \mathrm{H}-9 \beta), 2.51$ (1H, m, H-10), 1.63 (1H, m, H-11), 6.26 (IH, d, J = 2.7 Hz, H-13 $\alpha$ ), $5.52(\mathrm{IH}, \mathrm{d}, J=2.7 \mathrm{~Hz}, \mathrm{H}-$ $13 \beta), 1.12$ (3H, d, J = 6.2, H-14), 1.22 (3H, d, J = 6.2 Hz, H-15), 4.29 $\left(1 \mathrm{H}, \mathrm{d}, J=7.8 \mathrm{~Hz}, \mathrm{H}-1^{\prime}\right), 3.13(1 \mathrm{H}, \mathrm{t}, J=8.8 \mathrm{~Hz}, \mathrm{H}-2$ ') $3.32(1 \mathrm{H}, \mathrm{m}, \mathrm{H}-$ $\left.3^{\prime}\right), 3.25\left(1 \mathrm{H}, \mathrm{m}, \mathrm{H}-4^{\prime}\right), 3.24\left(1 \mathrm{H}, \mathrm{m}, \mathrm{H}-5^{\prime}\right), 3.81\left(1 \mathrm{H}, \mathrm{m}, \mathrm{H}-6^{\prime} \alpha\right), 3.63$ (1H, m, H-6' $\beta$ ); ${ }^{13} \mathrm{C}$ NMR (150 MHz, CD $\left.{ }_{3} \mathrm{OD}\right) \delta: 147.3$ (C-1), 35.0 (C-2), 36.2 (C-3), 76.1 (C-4), 122.2 (C-5), 23.8 (C-6), 48.1 (C-7), 82.2 (C-8), 36.8 (C-9), 33.9 (C-10), 40.0 (C-11), 181.2 (C-12), 17.1 (C-13), 9.0 (C14), 20.9 (C-15), 102.9 (C-1'), 74.0 (C-2'), 76.8 (C-3'), 70.3 (C-4'), 76.5 (C-5'), 61.5 (C-6').

\section{$2 \alpha$-Hydroxy-5 $\alpha H$-eudesma-4(15), 11(13)-dien-12,8 $\beta$-olide (Ivalin)} (3)

Amorphous white powder; IR (KBr, $\mathrm{V}_{\max } \mathrm{cm}^{-1}$ ): 3440, 2924, 1754, 1647, 1457, 1347, 1264, 1137; LC-MS $m / z$ 271.1294 [ M+Na] ${ }^{+}$(calcd. For $\left.\mathrm{C}_{15} \mathrm{H}_{20} \mathrm{O}_{3} \mathrm{Na}: 271.1310\right), 219.2698 \quad[2 \mathrm{M}+\mathrm{Na}]^{+}$(cald. For $\left.\mathrm{C}_{30} \mathrm{H}_{40} \mathrm{O}_{6} \mathrm{Na}: 519.2722\right) ;{ }^{1} \mathrm{H}$ NMR (600 MHz, $\left.\mathrm{CDCl}_{3}\right) \delta: 2.65(1 \mathrm{H}, \mathrm{m}, \mathrm{H}-$ $1 \alpha), 1.98(1 \mathrm{H}, \mathrm{m}, \mathrm{H}-1 \beta), 3.82$ (IH, ddd, $J=4.8,11.2,15.6 \mathrm{~Hz}, \mathrm{H}-2$ ),

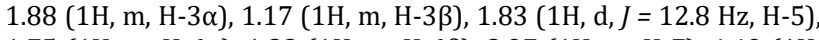
1.75 (1H, m, H-6 $\alpha), 1.33(1 \mathrm{H}, \mathrm{m}, \mathrm{H}-6 \beta), 2.97(1 \mathrm{H}, \mathrm{m}, \mathrm{H}-7), 4.49(1 \mathrm{H}$, $\mathrm{dd}, J=4.8,4.4 \mathrm{~Hz}, \mathrm{H}-8), 2.23(1 \mathrm{H}, \mathrm{dd}, J=1.3,14.0 \mathrm{~Hz}, \mathrm{H}-9 \alpha), 1.52(1 \mathrm{H}$, dd, $J=15.5,14.0 \mathrm{~Hz}, \mathrm{H}-9 \beta), 6.12(1 \mathrm{H}$, br. s, H-13 $\alpha$ ), 5.59 (1H, br. s, H-

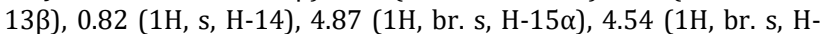
$15 \beta) ;{ }^{13} \mathrm{C}$ NMR (150 MHz, $\mathrm{CDCl}_{3}$ ) $\delta: 41.1$ (C-1), 67.1 (C-2), 46.3 (C-3), 146.0 (C-4), 45.6 (C-5), 27.3 (C-6), 40.5 (C-7), 76.7 (C-8), 51.0 (C-9), 34.0 (C-10), 141.9 (C-11), 170.6 (C-12), 120.5 (C-13), 18.8 (C-14), $109.4(\mathrm{C}-15)$

\section{Crispioside A (4)}

Colourless crystals; ${ }^{1} \mathrm{H}$ NMR (600 MHz, CD $\left.{ }_{3} \mathrm{OD}\right) \delta: 1.94(1 \mathrm{H}, \mathrm{m}, \mathrm{H}-1 \alpha)$, $1.28(\mathrm{IH}, \mathrm{m}, \mathrm{H}-1 \beta), 1.38(1 \mathrm{H}, \mathrm{ddd}, J=17.1,4.4,2.2 \mathrm{~Hz}, \mathrm{H}-2 \alpha), 1.34$ (1H, ddd, $J=17.1,15.1,5.1 \mathrm{~Hz}, \mathrm{H}-2 \beta), 2.13(1 \mathrm{H}, \mathrm{m}, \mathrm{H}-3 \alpha), 1.04(1 \mathrm{H}$, m, H-3ß), 1.53 (1H, m, H-5), $1.80(1 \mathrm{H}, \mathrm{dd}, J=6.8,14.2 \mathrm{~Hz}, \mathrm{H}-6 \alpha), 1.78$ $(1 \mathrm{H}, \mathrm{dt}, J=3.2,14.2 \mathrm{~Hz}, \mathrm{H}-6 \beta), 1.40(1 \mathrm{H}, \mathrm{m}, \mathrm{H}-7 \alpha), 0.98(1 \mathrm{H}, \mathrm{m}, \mathrm{H}-$

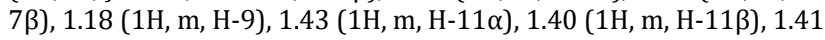
$(1 \mathrm{H}, \mathrm{m}, \mathrm{H}-12 \alpha), 0.99$ (1H, m, H-12ß), 2.52 (1H, m, H-13), $1.86(1 \mathrm{H}, \mathrm{m}$, $\mathrm{H}-14 \alpha), 0.90(1 \mathrm{H}, \mathrm{brs}, \mathrm{H}-14 \beta), 3.81(1 \mathrm{H}, \mathrm{dd}, J=2.0,3.0 \mathrm{~Hz}, \mathrm{H}-15)$, $5.26(1 \mathrm{H}, \mathrm{d}, J=3.0 \mathrm{~Hz}, \mathrm{H}-17 \alpha), 4.90(1 \mathrm{H}, \mathrm{d}, J=3.0, \mathrm{H}-17 \beta), 1.20(3 \mathrm{H}, \mathrm{s}$, H-19), 0.94 (3H, s, H-20), $5.38(1 \mathrm{H}, \mathrm{d}, J=8.0, \mathrm{H}-1$ '), 3.25 (1H, dd, $J=$ 8.0, $\left.9.5 \mathrm{~Hz}, \mathrm{H}-2^{\prime}\right), 5.27$ (1H, dd, $J=9.5,9.5 \mathrm{~Hz}, \mathrm{H}-3$ '), 3.35 (1H, dd, $J=$ 9.5, $\left.9.5 \mathrm{~Hz}, \mathrm{H}-4^{\prime}\right), 3.37$ (1H, m, H-5'), 3.67 (1H, dd, $J=2.5,12.5 \mathrm{~Hz}, \mathrm{H}-$ $\left.6^{\prime} \alpha\right), 3.65\left(1 \mathrm{H}, \mathrm{dd}, J=5.0,12.5, \mathrm{H}-6^{\prime} \beta\right), 4.41\left(1 \mathrm{H}, \mathrm{d}, J=8.0 \mathrm{~Hz}, \mathrm{H}-1^{\prime \prime}\right)$, 3.28 (1H, dd, J= 8.0, $\left.9.5 \mathrm{~Hz}, \mathrm{H}-2^{\prime \prime}\right), 3.34$ (1H, dd, $\left.J=9.5,9.5 \mathrm{~Hz}, \mathrm{H}-3^{\prime \prime}\right)$, 3.31 (1H, dd, $\left.J=9.5,9.5 \mathrm{~Hz}, \mathrm{H}-4^{\prime \prime}\right), 3.21$ (1H, m, H-5'), 3.89 (1H, dd, $J$ $=5.0,12.5 \mathrm{~Hz}, \mathrm{H}-6 " \alpha), 3.88\left(1 \mathrm{H}, \mathrm{dd}, \mathrm{J}=5.0,12.5 \mathrm{H}-6^{\prime \prime} \beta\right) ;{ }^{13} \mathrm{C}$ NMR (150 MHz, $\left.\mathrm{CDCl}_{3}\right) \delta: 37.9$ (C-1), 19.0 (C-2), 37.8 (C-3), 46.2 (C-4), 46.0 (C-5), 21.3 (C-6), 36.2 (C-7), 43.9 (C-8), 56.3 (C-9), 39.2 (C-10), 17.7 (C-11), 33.4 (C-12), 40.4 (C-13), 40.5 (C-14), 90.4 (C-15), 151.3 (C-16), 105.1 (C-17), 175.1 (C-18), 27.8 (C-19), 15.4 (C-20), 104.6 (C1'), 72.7 (C-2'), 76.2 (C-3'), 70.2 (C-4'), 72.7 (C-5'), 61.1 (C-6'), 94.2 (C-1'), 74.1 (C-2'), 76.2 (C-3'), 79.7 (C-4'), 77.0 (C-5"), 77.3 (C-6").

\section{Crispioside B (5)}

Colourless crystals; ${ }^{1} \mathrm{H}$ NMR (600 MHz, CD $\left.30 D\right) \delta: 1.81(1 \mathrm{H}, \mathrm{m}, \mathrm{H}-1 \alpha)$,

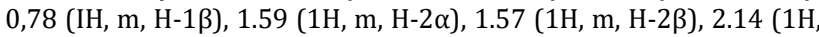
$\mathrm{m}, \mathrm{H}-3 \alpha), 1.95(1 \mathrm{H}, \mathrm{m}, \mathrm{H}-3 \beta), 1.08(1 \mathrm{H}, \mathrm{m}, \mathrm{H}-5), 1.98(1 \mathrm{H}, \mathrm{dd}, J=6.8$, $14.2 \mathrm{~Hz}, \mathrm{H}-6 \alpha), 1.81(1 \mathrm{H}, \mathrm{dt}, J=3.2,14.2 \mathrm{~Hz}, \mathrm{H}-6 \beta), 1.93(1 \mathrm{H}, \mathrm{m}, \mathrm{H}-$ $7 \alpha), 1.57(1 \mathrm{H}, \mathrm{m}, \mathrm{H}-7 \beta), 1.06(1 \mathrm{H}, \mathrm{m}, \mathrm{H}-9), 1.92(1 \mathrm{H}, \mathrm{m}, \mathrm{H}-11 \alpha), 1.90$

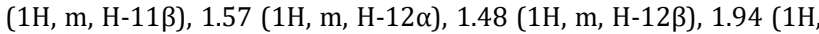
$\mathrm{m}, \mathrm{H}-13), 1.26(1 \mathrm{H}, \mathrm{m}, \mathrm{H}-14 \alpha), 0.88(1 \mathrm{H}, \mathrm{m}, \mathrm{H}-14 \alpha), 3.33(1 \mathrm{H}, \mathrm{m}, \mathrm{H}-$ $15 \alpha), 3.32(1 \mathrm{H}, \mathrm{m}, \mathrm{H}-15 \beta), 3.81(1 \mathrm{H}, \mathrm{d}, J=11.0 \mathrm{~Hz}, \mathrm{H}-17 \alpha), 3.56(1 \mathrm{H}$, d, $J=11.0 \mathrm{~Hz}, \mathrm{H}-17 \beta), 1.18(3 \mathrm{H}, \mathrm{s}, \mathrm{H}-19), 0.95(3 \mathrm{H}, \mathrm{s}, \mathrm{H}-20), 5.38(1 \mathrm{H}$, $\left.\mathrm{d}, J=8.0 \mathrm{~Hz}, \mathrm{H}-1^{\prime}\right), 3.30(1 \mathrm{H}, \mathrm{dd}, \mathrm{J}=8.0,9.5 \mathrm{~Hz}, \mathrm{H}-2$ '), $3.39(1 \mathrm{H}, \mathrm{dd}, J=$ 9.5, $\left.9.5 \mathrm{~Hz}, \mathrm{H}-3^{\prime}\right), 3.25$ (1H, dd, $\left.J=9.5,9.5 \mathrm{~Hz}, \mathrm{H}-4^{\prime}\right), 3.26(1 \mathrm{H}, \mathrm{m}, \mathrm{H}-$ $\left.5^{\prime}\right), 3.29\left(1 \mathrm{H}, \mathrm{m}, \mathrm{H}-6^{\prime} \alpha\right), 3.28\left(1 \mathrm{H}, \mathrm{m}, \mathrm{H}-6{ }^{\prime} \beta\right) ;{ }^{13} \mathrm{C}$ NMR $(150 \mathrm{MHz}$, $\mathrm{CD}_{3} \mathrm{OD}$ ) $\delta: ~ 40.5$ (C-1), 18.8 (C-2), 37.7 (C-3), 44.5 (C-4), 56.0 (C-5), 21.9 (C-6), 36.7 (C-7), 43.7 (C-8), 57.2 (C-9), 39.6 (C-10), 18.3 (C-11), 25.9 (C-12), 44.9 (C-13), $42.0(\mathrm{C}-14), 52.4(\mathrm{C}-15), 81.6(\mathrm{C}-16), 56.5$ (C-17), 176.9 (C-18), 27.7 (C-19), 15.0 (C-20), 94.3 (C-1'), 72.7 (C-2'), $77.4\left(\mathrm{C}-3\right.$ '), 69.8 (C-4'), 72.7 (C-5'), $61.1\left(\mathrm{C}-6^{\prime}\right)$.

\section{Quercetagetin 6, 7-dimethyl ether (Eupatolitin) (6)}

Amorphous white powder; ${ }^{1} \mathrm{H}$ NMR (600 MHz, $\left.\mathrm{CD}_{3} \mathrm{OD}\right) \delta: 6.71(1 \mathrm{H}, \mathrm{s}$, H-8), 6.62 (IH, d, $J=2.0 \mathrm{~Hz}, \mathrm{H}-2$ '), $6.88(1 \mathrm{H}, \mathrm{d}, J=8.5 \mathrm{~Hz}, \mathrm{H}-5$ ') 7.52 $(1 \mathrm{H}, \mathrm{dd}, \mathrm{J}=2.0,8.5 \mathrm{~Hz}, \mathrm{H}-6 \mathrm{\prime}), 3.76\left(3 \mathrm{H}, \mathrm{s}, \mathrm{OCH}_{3}\right), 3.94\left(3 \mathrm{H}, \mathrm{s}, \mathrm{OCH}_{3}\right)$; ${ }^{13} \mathrm{C}$ NMR (150 MHz, CD $\left.30 D\right) \delta: 154.5$ (C-2), 138.1 (C-3), 178.9 (C-4), 148.6 (C-5), 105.5 (C-6), 149.8 (C-7), 90.2 (C-8), 157.0 (C-9), 115.1 (C-10), 121.7 (C-1'), 121.0 (C-2'), 145.1 (C-3'), 145.3 (C-4'), 115.2 (C$\left.5^{\prime}\right), 129.5\left(\mathrm{C}-6\right.$ '), $55.1\left(\mathrm{OCH}_{3}\right), 59.1\left(\mathrm{OCH}_{3}\right)$.

\section{6-Methoxykaempferol (7)}

Yellow amorphous powder; ${ }^{1} \mathrm{H}$ NMR $\left(600 \mathrm{MHz}, \mathrm{CD}_{3} \mathrm{OD}\right) \delta: 6.45(1 \mathrm{H}$, s, H-8), 6.85 (IH, d, $\left.J=8.0 \mathrm{~Hz}, \mathrm{H}-2^{\prime}, 6^{\prime}\right), 8.05\left(1 \mathrm{H}, \mathrm{d}, J=8.0 \mathrm{~Hz}, \mathrm{H}-3^{\prime}, 5^{\prime}\right)$, $3.85\left(3 \mathrm{H}, \mathrm{s}, \mathrm{OCH}_{3}\right) ;{ }^{13} \mathrm{C}$ NMR $\left(150 \mathrm{MHz}, \mathrm{CD}_{3} \mathrm{OD}\right) \delta: 147.0(\mathrm{C}-2), 135.6$ (C-3), 176.3 (C-4), 152.3 (C-5), 131.0 (C-6), 157.1 (C-7), 93.4 (C-8), 151.7 (C-9), 104.0 (C-10), 122.4 (C-1'), 129.4 (C-2',6'), 115.0 (C$\left.3^{\prime}, 5^{\prime}\right), 159.3\left(\mathrm{C}-4^{\prime}\right), 59.6\left(\mathrm{OCH}_{3}\right)$.

\section{Patuletin 7-O- $\beta$-D-glucopyranoside (Patulitrin) (8)}

Yellow amorphous powder; ${ }^{1} \mathrm{H}$ NMR (600 MHz, $\left.\mathrm{CD}_{3} \mathrm{OD}\right) \delta: 3.28-3.86$ $\left(6 \mathrm{H}, \mathrm{m}, \mathrm{H}-2^{\prime \prime}-6^{\prime \prime}\right), 5.07$ (1H, d, J = $\left.8.0 \mathrm{~Hz}, \mathrm{H}-1^{\prime \prime}\right), 6.86$ (1H, s, H-8), 7.74 
(IH, d, $J=2.0 \mathrm{~Hz}, \mathrm{H}-2$ '), $6.85\left(1 \mathrm{H}, \mathrm{d}, J=8.5 \mathrm{~Hz}, \mathrm{H}-5^{\prime}\right), 6.65(1 \mathrm{H}, \mathrm{dd}, J=$ 2.0, $8.5 \mathrm{~Hz}, \mathrm{H}-6$ '), $3.86\left(3 \mathrm{H}, \mathrm{s}, \mathrm{OCH}_{3}\right) ;{ }^{13} \mathrm{C}$ NMR $\left(150 \mathrm{MHz}, \mathrm{CD}_{3} \mathrm{OD}\right) \delta$ : 147.7 (C-2), 132.0 (C-3), 176.3 (C-4), 156.3 (C-5), 100.7 (C-6), 162.0 (C-7), 95.0 (C-8), 151.8 (C-9), 114.8 (C-10), 122.6 (C-1'), 114.9 (C-2'), 144.9 (C-3'), 147.7 (C-4'), 120.6 (C-5'), 132.0 (C-6'), 105.3 (C-1"), 73.4 (C-2"), 77.2 (C-3"), 69.8 (C-4"), 77.4 (C-5"), 61.2 (C-6"), 60.2 $\left(\mathrm{OCH}_{3}\right)$.

\section{Patuletin 3-O- $\beta$-D-glucopyranoside (9)}

Yellow amorphous powder; ${ }^{1} \mathrm{H}$ NMR $\left(600 \mathrm{MHz}, \mathrm{CD}_{3} \mathrm{OD}\right) \delta: 3.20-3.67$ (6H, m, H-2"-6"), 5.23 (1H, d, $J=8.0 \mathrm{~Hz}, \mathrm{H}-1$ "), 6.48 (1H, s, H-8), 7.68 $\left(\mathrm{IH}, \mathrm{d}, J=2.0 \mathrm{~Hz}, \mathrm{H}-2\right.$ '), $6.84\left(1 \mathrm{H}, \mathrm{d}, J=8.5 \mathrm{~Hz}, \mathrm{H}-5^{\prime}\right), 7.55(1 \mathrm{H}, \mathrm{dd}, J=$ 2.0, $8.5 \mathrm{~Hz}, \mathrm{H}-6$ '), $3.84\left(3 \mathrm{H}, \mathrm{s}, \mathrm{OCH}_{3}\right) ;{ }^{13} \mathrm{C}$ NMR $\left(150 \mathrm{MHz}, \mathrm{CD}_{3} \mathrm{OD}\right) \delta$ : 157.5 (C-2), 133.9 (C-3), 178.4 (C-4), 144.6 (C-5), 94.3 (C-6), 157.8 (C-7), 93.6 (C-8), 152.3 (C-9), 104.8 (C-10), 121.7 (C-1'), 114.7 (C-2'), 131.3 (C-3'), 148.5 (C-4'), 116.2 (C-5'), 121.9 (C-6'), 101.9 (C-1"), 74.4 (C-2"), 77.0 (C-3"), 69.9 (C-4"), 78.1 (C-5"), 61.2 (C-6"), 59.7 $\left(\mathrm{OCH}_{3}\right)$.

\section{Antioxidant assay}

The antioxidant activity was determined by the DPPH free radical scavenging assay in triplicate and average values were considered [14]. Freshly prepared $(0.004 \% \mathrm{w} / \mathrm{v})$ methanol solution of 2, 2diphenyl-1-picrylhydrazyl (DPPH) radical was prepared and stored at $10{ }^{\circ} \mathrm{C}$ in the dark. A methanol solution of the test samples was prepared. A $40 \mu \mathrm{l}$ aliquot of the methanol solution was added to $3 \mathrm{ml}$ of DPPH solution. Absorbance measurements were recorded immediately with a UV-visible spectrophotometer (Miton Roy, Spectronic 1201). The decrease in absorbance at $515 \mathrm{~nm}$ was determined continuously, with data being recorded at 1 min intervals until the absorbance stabilized (16 min). The absorbance of the DPPH radical without antioxidant (control) and the reference compound ascorbic acid were also measured. All the determinations were performed in three replicates and averaged. The percentage inhibition (PI) of the DPPH radical was calculated according to the formula:

\section{$\mathrm{PI}=[\{(\mathrm{AC}-\mathrm{AT}) / \mathrm{AC}\} \times 100]$.}

Where; $\mathrm{AC}=$ Absorbance of the control at $\mathrm{t}=0 \mathrm{~min}$ and $\mathrm{AT}=$ Absorbance of the sample + DPPH at $t=16 \mathrm{~min}$.

\section{Cytotoxic assay}

The human breast adenocarcinoma cell line (MCF-7), and the human hepatocarcinoma cell line (Hep G2) cell line, which was purchased from the American Type Culture Collection (ATCC) USA, were used to evaluate the cytotoxic effect of the crude extract and the compounds. A control of untreated cells was made in the absence of the testing sample. A positive control containing doxorubicin drug was also tested as a reference drug for comparison. Six wells were used for each concentration of the tested samples. The number of the surviving cells was determined by staining the cells with crystal violet followed by cell lysing 33\% glacial acetic acid and read the absorbance at $590 \mathrm{~nm}$ using ELISA reader (SunRise, TECAN, inc, USA) after well mixing $[15,16]$. The absorbance values from untreated cells were considered as $100 \%$ proliferation. The number of viable cells was determined using ELISA reader as previously mentioned before and the percentage of viability was calculated as [1-(ODt/ODc)] $\times 100 \%$. Where ODt is the mean optical density of untreated cells. The $50 \%$ inhibitory concentration $\left(\mathrm{IC}_{50}\right)$, the concentration required to cause toxic effects in $50 \%$ of intact cells, was estimated from graphic plots.

\section{RESULTS AND DISCUSSION}

\section{Identification of purified compounds}

The extract $\mathrm{CH}_{2} \mathrm{Cl}_{2}-\mathrm{MeOH}$ (1:1) of $P$. undulata aerial parts were subjected to silica gel CC and reversed phase HPLC resulted in the isolation of nine secondary metabolites (1-9) (fig. 1). Of which three sesquiterpenes (1-3) were identified as 8-epi-ivalbin (1) [17], $11 \beta, 13$-dihydro-4H-xanthalongin 4-O- $\beta$-D-glucopyranoside (2) [18], ivalin (3) [19], two diterpenes (4-5) were identified as crispioside A (4) and crispioside B (5) [20], in addition to four flavonoids (6-9) were identified as; quercetagetin 6, 7-dimethyl ether (eupatolitin) (6) [21], 6-methoxykaempferol (7) [22], patuletin 7-O- $\beta$-D- glucopyranoside (patulitrin) (8) [23] and patuletin 3-0- $\beta$-Dglucopyranoside (9) [24]. Compounds (6), (7) and (8) firstly isolated from $P$. undulata and also previously isolated from other species of Pulicaria [21-23]. As far as could be ascertained, this is the first report of compounds (1) and (2) from the genus Pulicaria.

\section{Determination of antioxidant activity}

Although various assays were reported to estimate the free radical scavenging activity [25], one common method is DPPH. The change in absorbance produced by reducing DPPH was used to evaluate the ability of testing compounds as antioxidant activity. Based on the principle, the antioxidant of the tested samples can be expressed as its ability in scavenging the DPPH radicals. The dose-response curves for the tested samples showed that for each sample six concentrations $(\mu \mathrm{g} / \mathrm{ml})$ were tested (fig. 2$)$. It was found that the crude extract and the isolated compounds of $P$. undulata showed variable degrees of free radical scavenging property that increased in a dose-dependent manner. The inhibition percentage of DPPH radical formation ranged from $18.9 \%$ to $96.3 \%$ at the highest tested dose $(128 \mu \mathrm{g} / \mathrm{ml})$ and from $3.8 \%$ to $23.1 \%$ at the lowest tested dose $(1 \mu \mathrm{g} / \mathrm{ml})$ (fig. 2). The obtained results showed that the DPPH scavenging percentage of the different tested samples at the same concentration $(128 \mu \mathrm{g} / \mathrm{ml})$ is as follows: 6-methoxykaempferol (7) (96.3\%)>eupatolitin (6) (94.7\%)>patuletin 3-0- $\beta$-D-glucopyranoside (9) (91.3\%)>patulitrin (8) $(90.8 \%)>$ the crude extract $\left(\mathrm{CH}_{2} \mathrm{Cl}_{2} / \mathrm{MeOH}\right)(76.2 \%)>$ ivalbin (1) $(61.5 \%)$, with the $\mathrm{IC}_{50}$ values of $2.3,2.7,6.0,6.7,43.9$ and $93.4 \mu \mathrm{g} / \mathrm{ml}$ respectively.

However, the other compounds $11 \beta, 13$-dihydro-4H-xanthalongin 4-0$\beta$-D-glucopyranoside (2), ivalin (3), crispioside A (4) and crispioside B (5) showed poor antioxidant activity, the values of DPPH scavenging percentage are 18.9, 23.7, 27.3 and $38.9 \%$ respectively.
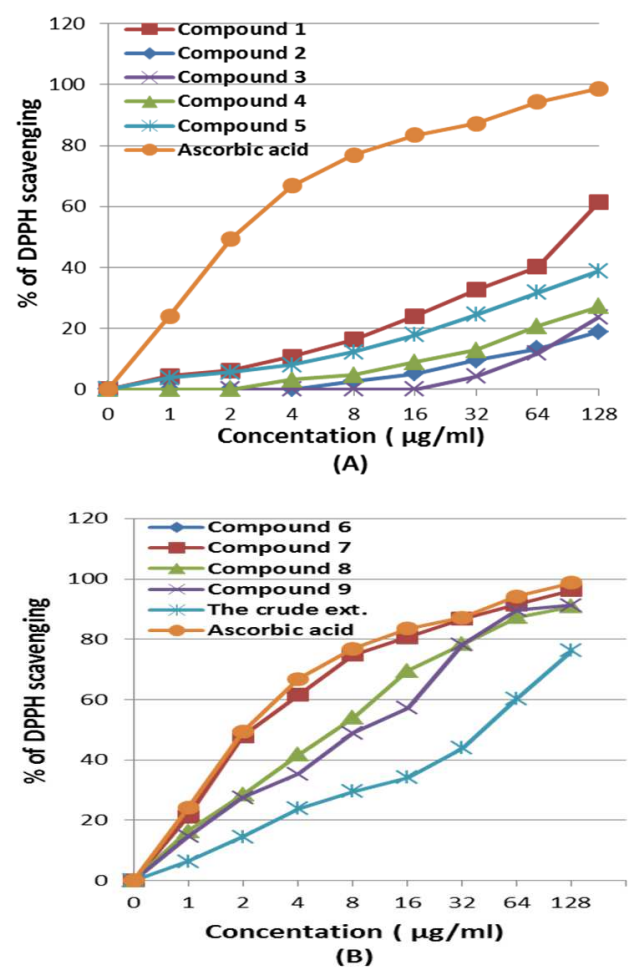

Fig. 2: A) Antioxidant activity of terpenoids (1-5), B) Flavonoids (6-9) and the crude extract compared with standard Ascorbic acid

Data are means \pm standard deviation of triplicate experiments

\section{Determination of cytotoxic activity}

Cancer is a public health problem all over the world [26]. A Large number of plants and their isolated constituents has been shown to 
possess potential anticancer activity. The cytotoxic activity of the crude extract and the isolated compounds of $P$. undulata were also assessed against MCF-7 and Hep G2 cells. We have examined the effect of each sample on the proliferation of MCF-7 and Hep G2 cells in vitro at six different concentrations $(3.125-100 \mu \mathrm{g} / \mathrm{ml})$ using the viability assay. The results obtained from this study showed that the tested samples inhibited the proliferation of MCF-7 cells (fig. 3) and Hep G2 cells (fig. 4) at various levels, and the cytotoxic activity increased in a dose-dependent manner. The strongest cytotoxic effect was obtained, with compound 6 against MCF-7 cells (IC $5_{50} 27$ $\mu \mathrm{g} / \mathrm{ml}$ ), followed by compound $2,7,3,4,1$ and 8 with respective $\mathrm{IC}_{50 \mathrm{~S}}$ of $35.9,37.3,39.6,47.9,62.1$ and $87.1 \mu \mathrm{g} / \mathrm{ml}$. The MCF-7 cells were resistant to compounds 5 and 9 that also showed a weak cytotoxicity against Hep G2 cells. On the other hand, compound 6 is also the strongest cytotoxic effect against Hep G2 cells (IC 50 $_{2} 23.5$ $\mu \mathrm{g} / \mathrm{ml}$ ), followed by compound $3,2,7,4,8,1,5$ and 9 with respective $\mathrm{IC}_{50} \mathrm{~S}$ of 31.6, 39.5, 40.2, 49.6, 72.0, 80.1, 82.3 and $85.0 \mu \mathrm{g} / \mathrm{ml}$. In addition, the crude extract $\left(\mathrm{CH}_{2} \mathrm{Cl}_{2} / \mathrm{MeOH}\right)$ showed a good cytotoxic activity against both MCF-7 cells and Hep G2 cells with IC $_{50} 41.6$ and $40.7 \mu \mathrm{g} / \mathrm{ml}$ respectively.

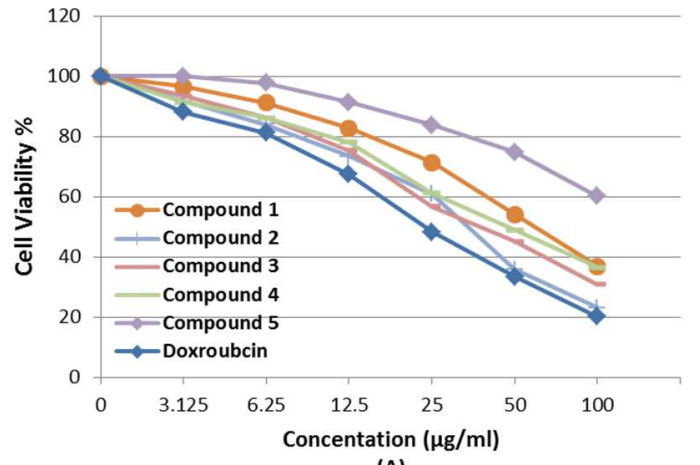

(A)

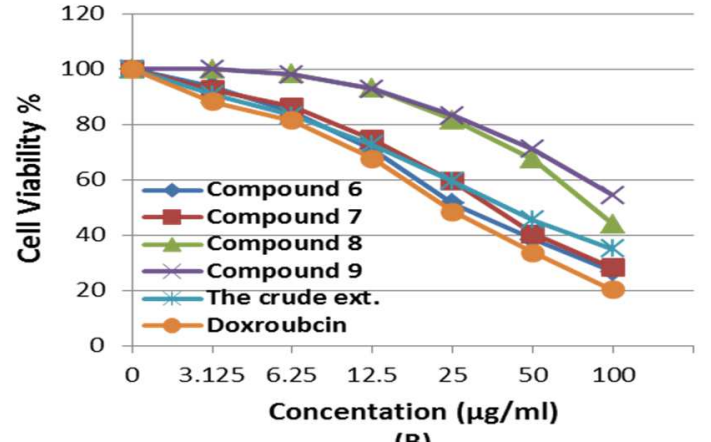

(B)

Fig. 3: A) Cytotoxic activity of terpenoids (1-5), B) Flavonoids (6-9) and the crude extract compared to Doxorubicin as positive control on MCF-7 cells in vitro

Data are means \pm standard deviation of triplicate experiments

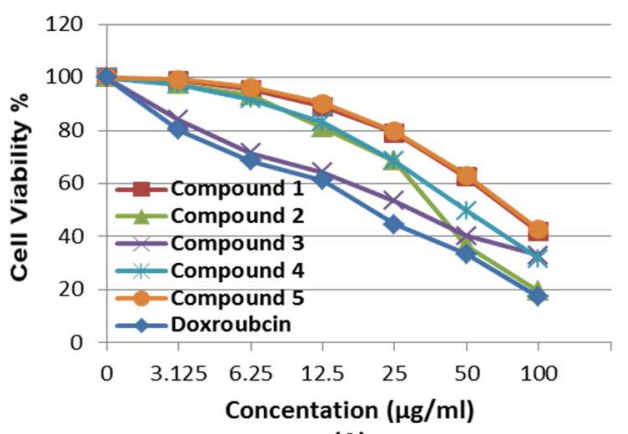

(A)

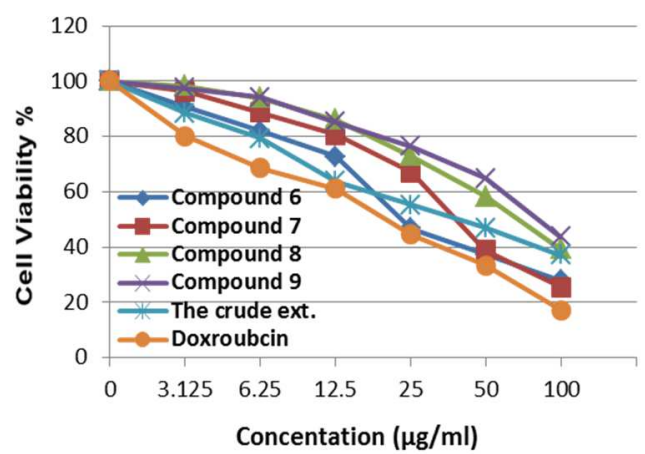

(B)

Fig. 4: A) Cytotoxic activity of terpenoids (1-5), B) Flavonoids (6-9) and the crude extract compared to Doxorubicin as positive control on Hep G2 cells in vitro

Data are means \pm standard deviation of triplicate experiments

\section{Structures-activity relationship}

Flavonoids are powerful antioxidant against free radicals because they act as "radical scavengers". This activity is attributed to their hydrogen-donating ability. Where the phenolic groups of flavonoids serve as a source of a ready available " $\mathrm{H}$ " atoms, allowing as delocalization over the flavonoids structure of the subsequent radicals produced. In fact, the antioxidant capacity of a flavonoid is linked to its particular chemical structures [27, 28].

Compound 7 ( $\left.\mathrm{IC}_{50} 2.3 \mu \mathrm{g} / \mathrm{ml}\right)$ showed the most potent $\mathrm{DPPH}$ scavenger in this study, not only possesses the 2, 3-double bond in conjugation with 4-oxo function in the C-ring, responsible for the electron dislocation from the B-ring, but also possesses both 3 and 5-hydroxyl groups and another free 7-OH in the A-ring, which are among the essential structural elements of potent radical-scavenging activities of the flavonoids [28, 29]. Compound $6\left(\mathrm{IC}_{50} 2.7 \mu \mathrm{g} / \mathrm{ml}\right.$ ) is also a potent antioxidant and came in the second rank, possesses a 3', 4'-catechol structure in the B-ring, which confers greater stability to aroxyl radicals, possibly through hydrogen bonding, and which participates in the electron dislocation $[30,31]$. Also, it possesses the 2,3-double bond in conjugation with a 4-oxo function and both 3 and 5-hydroxyl groups. On the other hand, the presence of two methoxy groups at 6 and 7 positions (Methoxylation) in compound 6 might play a certain role in reducing its antioxidant activity when compared with compound 7 [27, 32]. Although, both compound 8 (IC $50.7 \mu \mathrm{g} / \mathrm{ml}$ ) and compound 9 (IC $506.0 \mu \mathrm{g} / \mathrm{ml}$ ) possesses the 2,3double bond in conjugation with a 4-oxo function and 3', 4'-catechol structure, but their antioxidant activity highly reduced compared to compounds 6 and 7. The combination of a glucose moiety of compounds 8 and 9 at 7 and 3 positions respectively, may be playing an important role in reducing their antioxidant activity $[28,29]$. On the other hand, the sesquiterpenoidal compound 1 ( $\mathrm{IC}_{50} 93.4 \mu \mathrm{g} / \mathrm{ml}$ ), showing the lowest antioxidant potency, the presence of two free hydroxyl groups, one $\mathrm{CH}_{3}$ and one $\mathrm{CH}_{2}$ in its structure, seems to confer only satisfies reducing potential. However, the other terpenoids 2, 3, 4 and 5 showed poor antioxidant activity, the DPPH scavenging percentage of them less than $40 \%$.

The highest cytotoxic effect against MCF-7 and Hep G2 cells was obtained with compound 6 (IC 27.6 and $23.5 \mu \mathrm{g} / \mathrm{ml}$ ) respectively; this activity could be explained by the presence of a C2-C3 double bond and the 3-hydroxyl group of the ring A that important factors for the anti-proliferative activity of flavonoids [33]. Compound 7 is also a potent cytotoxic activity against MCF-7 and Hep G2 cells ( IC $_{50}$ 37.3 and $40.2 \mu \mathrm{g} / \mathrm{ml}$ ) respectively and came in the second rank after compound 6. Comparing compound 6 and 7 , it is concluded that hydroxylation at C-5' and 0-methylation at C-7 in compound 6 seem to enhance its cytotoxicity more than compound $7[34,35]$. In fact, the presence of methoxyl substituent has modulated the cytotoxicity of flavonoids [36-38]. The presence of 7-0 glucose in compound 8 instead of the 7-methoxy group in compound 6, highly reduced the 
cytotoxicity of compound 8 (IC $\mathrm{I}_{50} 87.1$ and $72 \mu \mathrm{g} / \mathrm{ml}$ ) compared with compound 6 ( $\mathrm{IC}_{50} 27.6$ and $23.5 \mu \mathrm{g} / \mathrm{ml}$ ) against MCF-7 and Hep G2 cells respectively. Compound 9 is the lowest cytotoxic activity against MCF-7 and Hep G2 cells, $\left(\mathrm{IC}_{50}>100\right.$ and $\left.85 \mu \mathrm{g} / \mathrm{ml}\right)$ respectively, that possesses 3-0 glucose and 7-OH instead of 3-OH and 7-methoxy groups in compound 6 . We can conclude that the presence of both 3-free hydroxyl group and the 7-methoxy group is essential for flavonoids cytotoxicity.

The terpenoidal compounds 1-5 showed the variable potency of cytotoxic activity, compound 2 (IC 5035.9 and $39.5 \mu \mathrm{g} / \mathrm{ml}$ ) and compound 3 ( $\mathrm{IC}_{50} 39.6$ and $31.6 \mu \mathrm{g} / \mathrm{ml}$ ) showed the most potent cytotoxic against MCF-7 and Hep G2 cells, respectively, compared with the other terpenoids. The cytotoxicity of compound 2 and 3 could be explained by the presence of a number of $\mathrm{CH}_{2}$ and $\mathrm{CH}_{3}$ groups in both skeletons that enhanced their polarity and cytotoxicity $[39,40]$. Also, the presence of 4-0 glucose in compound 2 instead of the free 4-OH group in compound 1, highly enhanced the cytotoxicity of compound 2 ( $\mathrm{IC}_{50} 35.9$ and $39.5 \mu \mathrm{g} / \mathrm{ml}$ ) more than compound $1\left(\mathrm{IC}_{50} 62.1\right.$ and $\left.80.5 \mu \mathrm{g} / \mathrm{ml}\right)$ against MCF-7 and Hep G2 cells, respectively. On the other hand, compound 4 ( IC $_{50} 47.9$ and $49.6 \mu \mathrm{g} / \mathrm{ml}$ ) is more potent in cytotoxicity than compound 5 (IC I0 $_{50}>100$ and $82.3 \mu \mathrm{g} / \mathrm{ml}$ ) against MCF-7 and Hep G2 cells, respectively, compound 4 is highly more polar than compound 5 , that may play important role in enhancing its cytotoxicity [39, 40].

To the authors' knowledge, this is the first report concerning the antioxidant and cytotoxic terpenoids and flavonoids from $P$. undulata with the study of their structure-activity relationship.

\section{CONCLUSION}

In this study, the antioxidant and cytotoxic potential of flavonoids and terpenoids isolated from $P$. undulata aerial part were evaluated using in vitro DPPH and the viability assay, respectively. The findings presented here showed that 3, 5, 7, 4' and 3, 5, 4', 5'-hydroxy flavonoids were a potent antioxidant and cytotoxic activity. It can suggest that the $\mathrm{C} 2-\mathrm{C} 3$ double bond, in conjugation with a 4-oxo function in the $\mathrm{C}$-ring and $\mathrm{OH}$ substitution on the A-ring play important roles in the antioxidant and cytotoxic capacity of these flavonoids. Furthermore, the ortho-dihydroxy (catechol) structure in the B-ring and the 7-methoxylation in the A-ring also affect significantly the antioxidant and cytotoxic potential. On the other hand, among the tested terpenoids in this study, the presence of a number of $\mathrm{CH}_{3}, \mathrm{CH}_{2}$ and sugar moiety in sesqui/diterpenes skeletons gives their molecules a polar character that enhances the cytotoxic activity. The investigation of such structure-activity relationship in this study afforded important information that may participate in the development of the future design for antioxidant and cytotoxic agents

\section{CONFLICT OF INTERESTS}

\section{Declared none}

\section{REFERENCES}

1. El-Shemy H, Aboul-Enein A, Aboul-Enein M, Issa S, Fujita K. The effect of willow leaf extract on human leukemic cells, in vitro. J Biochem Mol Biol 2003;36:387-9.

2. El-Shemy HA, Aboul-Enein AM, Aboul-Enein KM, Fujita K Willow leaves' extracts contain anti-tumor agents effective against three cell types. PLoS One 2007;2:178.

3. Vickers A. Botanical medicines for the treatment of cancer: rationale, an overview of current data, and methodological considerations for phase I and II trials. Cancer Invest 2002;20:1069-79.

4. Williams CA, Harborne BJ, Greenham JR, Grayer JR, Kite CG, Eagles J. Variations in lipophilic and vacuolar flavonoids among European Pulicaria species. Phytochemistry 2003;64:275-83.

5. Liu LL, Yang JL, Shi YP. Phytochemicals and biological activities of Pulicaria species. Chem Biodiversity 2010;7:327-49.

6. Al-Yahya AM, El-Sayed MA, Mossa SJ, Kozlowski FJ, Antoun DM, Ferin M, et al. Potential cancer chemopreventive and cytotoxic agents from Pulicaria crispa. J Nat Prod 1988;51:621-4.

7. Awadh AU, Juelich NA, Kusnick WO, Lindequist CU. Screening of Yemeni medicinal plants for antibacterial and cytotoxic activities. J Ethnopharmacol 2001;74:173-9.
8. EL-Kamali HH, Ahmed AH, Mohammed AS, Yahia AAM, ELTayeb IH, Ali AA. Antibacterial properties of essential oils from Nigella sativa seeds, Cymbopogon citratus, leaves and Pulicaria undulata aerial parts. Fitoterapia 1998;1:77-8.

9. Basta A, Tzakou O, Couladis M, Pavlovic M. Chemical composition of Pulicaria dysenterica (L.) Bernh. from Greece. J Essent Oil Res 2007;19:333-5.

10. Ezoubeiri A, Gadhi CA, Fdil N, Benharref A, Vanhaelen M. Isolation and antimicrobial activity of two phenolic compounds from Pulicaria odora L. J Ethnopharm 2005;99:287-92.

11. Tanira MOM, Ali BH, Bashir AK, Wasfi IA, Chandranath I. Evaluation of the relaxant activity of some United Arab Emirates plants on intestinal smooth muscle. J Pharm Pharmacol 1996;48:545-50.

12. Mahfouz M, Ghazal A, El-Dakhakhny M, Ghoneim MT. Pharmacological studies on the active principle isolated from Pulicaria dysenterica. J Drug Res 1973;5:151-72.

13. Hegazy M, Matsuda H, Nakamura S, Yabe M, Matsumoto T, Yoshikawa M. Sesquiterpenes from an Egyptian herbal medicine, Pulicari undulata, with inhibitory effects on nitric oxide production in RAW264.7 macrophage cells. Chem Pharm Bull 2012;60:363-70.

14. Yen GC, Duh PD. Scavenging effect of methanolic extract of peanut hulls on free radical and active oxygen species. J Agric Food Chem 1994;42:629-32.

15. Mosamnn T. Rapid colorimetric assay for cellular growth and survival: application to proliferation and cytotoxicity assays. J Immunol Methods 1983;65:55-63.

16. Gangadevi V, Muthumary J. Preliminary studies on the cytotoxic effect of fungal taxol on cancer cell lines. Afr J Biotechnol 2007;6:1382-6.

17. Herz W, Chikamatsu H, Viswanathan N, Sudarsanam V. Constituents of Iva species. VIII. The structure of ivalbin, a modified guaianolide from Iva dealbata Gray. J Org Chem 1967;32:682-6.

18. Claus MP, Irmgard M, Christoph B, Günter W, Alois S. 11a,13and 11b,13-Dihydro-4H-xanthalongin 4-0Glucopyranosides: new sesquiterpene lactone glycosides from flowers of Arnica amplexicaulis and A. mollis. Planta Med 1996;62:39-41.

19. Karamenderes C, Bedir E, Abou-Gazar H, Khan AI. Chemical constituents of Centaurea cadmea. Chem Nat Compd 2007;43:694-5.

20. Abdel-Mogib M, Jakupovic J, Dawidar AM, Metwally MA, AbouElzahab M. Sesquiterpene lactones and kaurane glycosides from Francoeuria crispa. Phytochemistry 1990;29:2581-4.

21. Eckhard W, Abdolhossein R. Exudate flavonoids in three Persian asteraceae species. Biochem Syst Ecol 1991;19:673-5.

22. Takaharu H, Hajime A, Hiroto C, Shigeharu F, Masashi K. Isolation and identification of anti-Helicobacter pylori compounds from Polygonum tinctorium Lour. Nat Med 1999;53:27-31.

23. Christine AW, Jeffrey BH, Jenny RG, Rene'e JG, Geoffrey CK, John E. Variations in lipophilic and vacuolar flavonoids among European Pulicaria species. Phytochemistry 2003;64:275-83.

24. Wiesława B. A new acylated flavonol diglycoside from Atriplex littoralis. Acta Physiol Plant 2004;26:393-8.

25. Pal RS, Ariharasivakumar G, Girhepunjhe K, Upadhay A. In the vitro antioxidative activity of phenolic and flavonoids compounds extracted from seeds of Abrus precatorius. Int J Pharm Pharm Sci 2009;1:136-40.

26. Francis D, Rita L. Rapid colorimetric assay for cell growth and survival: modifications to the tetrazolium dye procedure giving improved sensitivity and reliability. J Immunol Methods 1986;89:271-7.

27. Burda S, Oleszek W. Antioxidant and antiradical activities of flavonoids. J Agric Food Chem 2001;49:2774-9.

28. Di Majo D, Giammanco M, La Guardia M, Tripoli E, Giammanco S, Finotti E. Flavanones in citrus fruit: structure-antioxidant activity relationships. Food Res Int 2005;38:1161-6.

29. Benavente-Garcia O, Castillo J, Marin FR, Ortuno A, Del Rio JA. Uses and properties of citrus flavonoids. J Agric Food Chem 1997;45:4505-15.

30. Bors W, Hellers W, Michel C, Saran M. Radical chemistry of flavonoids. Adv Exp Med Biol 1990;264:165-70. 
31. Bors W, Hellers W, Michel C, Saran M. Flavonoids as antioxidants: determination of radical-scavenging efficiencies. Methods Enzymol 1990;186:343-55.

32. Arora A, Nair MG, Strasburg GM. Structure-activity relationships for antioxidant activities of a series of flavonoids in a liposomal system. Free Radical Biol Med 1998;24:1355-63.

33. Rusakc G, Gutzeita HO, Muller JL. Structurally related flavonoids with antioxidative properties differentially affect cell cycle progression and apoptosis of human acute leukemia cells. Nutr Res 2005;25:141-53.

34. Plochmann K, Korte G, Koutsilieri E, Richling E, Riederer P, Rethwilm A, et al. Structure-activity relationships of flavonoidinduced cytotoxicity on human leukemia cells. Arch Biochem Biophys 2007:460:1-9.

35. Li F, Awale S, Tezuka Y, Kadota S. Cytotoxic constituents from Brazilian red propolis and their structure-activity relationship. Bioorg Med Chem 2008;16:5434-40.

36. Ducki S, Forrest R, Hadfield JA, kendall A, Lawrence NJ, Mcgown $\mathrm{AT}$, et al. Potent antimitotic and cell growth inhibitory properties of substituted chalcones. Bioorg Med Chem Lett 1998;8:1051-6.
37. Pouge TC, Lauthier F, Simon A, Fagnere C, Basly JP, Delage C, et al. Flavonoids: structural requirements for antiproliferative activity on breast cancer cells. Bioorg Med Chem Lett 2001;11:3095-7.

38. Militao GC, Dantas IN, Pessoa C, Falcao MJ, Silveira ER, Lima $\mathrm{MA}$, et al. Induction of apoptosis by pterocarpans from Platymiscium floribundum in HL-60 human leukemia cells. Life Sci 2006;78:2409-17.

39. Wang IK, Lin-Shiau SY, Lin JK. Induction of apoptosis by apigenin related flavonoids trough cytochrome $\mathrm{c}$ release and activation of caspase- 9 and caspase-3 in leukemia HL-60 cells. Eur J Cancer 1999;35:1517-25.

40. Kawaii S, Tomono Y, Katase E, Ogawa K, Yano M. Effect of citrus flavonoids on HL-60 cell differentiation. Anticancer Res 1999;19:1261-70.

\section{How to cite this article}

- Taha A Hussien, Sayed A EL-Toumy, Hossam M Hassan, Mona H Hetta. Cytotoxic and antioxidant activities of secondary metabolites from Pulicaria undulata. Int J Pharm Pharm Sci 2016;8(9):150-155. 